\title{
Colon or Rectum Neuroendocrine Tumor pT3 TNM Finding v7
}

National Cancer Institute

\section{Source}

National Cancer Institute. Colon or Rectum Neuroendocrine Tumor PT3 TNM Finding v7. NCl Thesaurus. Code C90107.

Colon or rectum neuroendocrine tumor invading through the muscularis propria into the subserosa, or into non-peritonealized pericolic or perirectal tissues. (from AJCC 7th Ed.) 